medRxiv preprint doi: https://doi.org/10.1101/2021.06.22.21259358; this version posted June 25, 2021. The copyright holder for this preprint (which was not certified by peer review) is the author/funder, who has granted medRxiv a license to display the preprint in All rights reserved. No reuse allowed without permission.

\title{
RGC-TBRS Personal Air Pollutant Exposure versus Health Condition and Perception Pilot Study for Young Asthmatics in Hong Kong (2019/2020)
}

\author{
Kenyon Chow ${ }^{1 \#}$, Yang Han ${ }^{1 \#}$, Victor OK Li ${ }^{1 \# *}$, Jacqueline CK Lam ${ }^{1 \# *}$, So-lun Lee $^{2}$, Wilfred \\ Wong ${ }^{2}$, Yu-lung Lau ${ }^{2}$ \\ ${ }^{1}$ Department of Electrical and Electronic Engineering, The University of Hong Kong \\ ${ }^{2}$ Queen Mary Hospital, The University of Hong Kong \\ * Corresponding Authors \\ \# Equal contributions
}

\section{Abstract}

This is a report of the RGC-TBRS funded observational pilot study which examines the effects of personal exposures to three types of air pollutants, namely, $\mathrm{PM}_{1.0}, \mathrm{PM}_{2.5}$, and $\mathrm{PM}_{10}$, on personal health condition and perception of young asthmatics (aged 12 - 15) in Hong Kong. This is the first study to investigate the relationship between $\mathrm{PM}_{1.0}$ and $\mathrm{FEV}_{1}$ and FVC of young asthmatics in Hong Kong, based on personal exposures obtained from portable sensors. Our preliminary results show that a higher level of $\mathrm{PM}_{1.0}, \mathrm{PM}_{2.5}$ and $\mathrm{PM}_{10}$ would deteriorate the health conditions of young asthmatics in HK. All correlations between particulates and lung functions are significant and negative, including $\mathrm{PM}_{1.0}$ exposure vs. $\mathrm{FEV}_{1}\left(\mathrm{R}^{2}=12 \% ; p=0.023\right)$, $\mathrm{PM}_{1.0}$ exposure vs. FVC $\left(\mathrm{R}^{2}=15 \% ; p=0.010\right), \mathrm{PM}_{2.5}$ exposure vs. $\mathrm{FEV}_{1}\left(\mathrm{R}^{2}=13 \% ; p=0.019\right)$, $\mathrm{PM}_{2.5}$ exposure vs. FVC ( $\left.\mathrm{R}^{2}=16 \% ; p=0.008\right), \mathrm{PM}_{10}$ exposure vs. $\mathrm{FEV}_{1}\left(\mathrm{R}^{2}=14 \% ; p=0.012\right)$, and $\mathrm{PM}_{10}$ exposure vs. FVC $\left(\mathrm{R}^{2}=18 \% ; p=0.005\right)$. Moreover, after accounting for covariates, including age, gender, body mass index (BMI), temperature, and relative humidity, we found a significant relationship between $\mathrm{PM}_{1.0}$ exposure vs. FVC (Coefficient=-0.1224; $p=0.032$ ), $\mathrm{PM}_{2.5}$ exposure vs. FVC (Coefficient=-0.1177; $\left.p=0.021\right), \mathrm{PM}_{10}$ exposure vs. $\mathrm{FEV}_{1}$ (Coefficient=-0.0703; $p=0.019$ ), and $\mathrm{PM}_{10}$ exposure vs. FVC (Coefficient=-0.1204; $p=0.006$ ). Further, using the pilot study data, we have performed a power analysis to estimate the sample size for our follow-up main study. Based on the primary null hypothesis that personal PM exposure would not change the $\mathrm{FEV}_{1}$ and FVC of young asthmatics in $\mathrm{HK}$, the lowest sample size that gives $80 \%$ power at a $5 \%$ significance level is 107 . Hence, the sample size (or the total number of participated asthma subjects) expected for the follow-up longitudinal clinical study should be 125 (after adjusting for the non-compliance and withdrawal of subjects). Our pilot study has demonstrated the feasibility of research into the effects of personal air pollutant NOTE: This preprint reports new research that has not been certified by peer review and should not be used to guide clinical practice. exposure on health condition and health perception. Our follow-up study will address the 
medRxiv preprint doi: https://doi.org/10.1101/2021.06.22.21259358; this version posted June 25, 2021. The copyright holder for this preprint (which was not certified by peer review) is the author/funder, who has granted medRxiv a license to display the preprint in All rights reserved. No reuse allowed without permission.

challenges identified in the pilot study, based on the proposed follow-up actions for subject engagement, data collection, and data analysis.

\section{Introduction}

Previous air pollution and public health studies conducted internationally and in Hong Kong (HK) showed that exposures to outdoor air pollutants are correlated with the health conditions of young asthmatics. Panel studies provided the preliminary evidence for the cumulative effect of air pollutants on health conditions over time. A recent review of over 30 relevant panel studies showed that the adverse effects of air pollutant exposures on health conditions are more pronounced in asthmatic children than in healthy children [1, 2, 3, 4]. However, three major gaps have been identified from the previous studies. First, most of these panel studies are limited to the US and European contexts. Second, previous exposure assessment methods tend to use aggregate rather than personal air pollutant exposure data [5]. Further, the relationship between air pollutant exposures and health perceptions of the asthmatics is often overlooked. Until now, two important research questions are yet to be fully addressed: (1) Would a higher level of personal air pollutant exposures result in poorer health conditions among young asthmatics in HK? (2) Would a higher level of personal air pollutant exposures result in more negative health perceptions among the young asthmatics in HK?

This study aims to fill the above research gaps and investigate how personal air pollutant exposures will affect health conditions and perceptions. A pilot study was conducted during Sep 2019 - Oct 2020. 51 asthma subjects were shortlisted, and nine subjects participated in the study and finished their pilot runs. This report summarizes the results of the pilot study. The report is organized as follows. Section 2 details the data collection methodology and statistical analysis. Section 3 presents the preliminary results based on the pilot run data, compares the results with the previous literature, and calculates the sample size for our follow-up study. Section 4 lists the major challenges of the pilot study. Section 5 proposes recommendations for our follow-up study. Section 6 concludes the pilot study.

\section{Data and Methodology}

\subsection{Data Collection during the Pilot Study}

The pilot study was conducted on a rolling basis during Sep 2019 - Oct 2020. The subject recruitment was conducted by the Department of Pediatrics in Queen Mary Hospital (QMH). The pilot study targeted young asthma subjects aged 12 to 17 . As of mid-Oct 2020, 51 asthma subjects were shortlisted, and nine asthma subjects (aged 12 to 15) participated in the study 
medRxiv preprint doi: https://doi.org/10.1101/2021.06.22.21259358; this version posted June 25, 2021. The copyright holder for this preprint (which was not certified by peer review) is the author/funder, who has granted medRxiv a license to display the preprint in All rights reserved. No reuse allowed without permission.

and finished their pilot runs. After subject enrolment, demographic information was collected through a one-off background survey (Table 1a). During the pilot study, for each subject, personal air pollutant exposure, health condition, and health perception data were continuously collected with a portable air pollution sensor, three portable/wearable devices (e-inhaler, espirometer, and Mi-Band), and a set of validated health-related surveys (Tables 1b-1d).

Table 1. Data collection frequencies and types

(a) Demographic information

\begin{tabular}{|l|l|l|l|}
\hline Instrument & $\begin{array}{l}\text { Sampling } \\
\text { frequency }\end{array}$ & $\begin{array}{l}\text { Data } \\
\text { format }\end{array}$ & Data types \\
\hline $\begin{array}{l}\text { Paper-based } \\
\text { survey }\end{array}$ & Once & CSV * & $\begin{array}{l}\text { Demographic information such as age, } \\
\text { gender, weight, and height }\end{array}$ \\
\hline $\begin{array}{l}\text { Notes: } \\
* \text { A CSV file is a comma-separated values file that stores data in a tabular format. }\end{array}$ \\
\hline
\end{tabular}

(b) Personal air pollutant exposure

\begin{tabular}{|l|l|l|l|}
\hline Instrument & $\begin{array}{l}\text { Sampling } \\
\text { frequency }\end{array}$ & $\begin{array}{l}\text { Data } \\
\text { format }\end{array}$ & Data types \\
\hline Portable sensor & 1 minute & CSV & $\begin{array}{l}\text { Time, date, GPS longitude, GPS latitude, } \\
\text { GPS altitude, temperature, relative humidity, } \\
\text { background noise, three-axis accelerations, } \\
\mathrm{PM}_{1.0}, \mathrm{PM}_{2.5}, \mathrm{PM}_{10}\end{array}$ \\
\hline $\begin{array}{l}\text { Notes: } \\
\text { * PM}\end{array}$ & $\begin{array}{l}\text { from particle counts using the manufacturer's default parameters. Temperature and } \\
\text { humidity measurements (at sensor) are adjusted to reflect external temperature and relative } \\
\text { humidity. }\end{array}$ \\
\hline
\end{tabular}

(c) Health condition

\begin{tabular}{|l|l|l|l|}
\hline Instrument & $\begin{array}{l}\text { Sampling } \\
\text { frequency }\end{array}$ & $\begin{array}{l}\text { Data } \\
\text { format }\end{array}$ & Data types \\
\hline
\end{tabular}


medRxiv preprint doi: https://doi.org/10.1101/2021.06.22.21259358; this version posted June 25, 2021. The copyright holder for this preprint (which was not certified by peer review) is the author/funder, who has granted medRxiv a license to display the preprint in All rights reserved. No reuse allowed without permission.

\begin{tabular}{|c|c|c|c|}
\hline E-inhaler * & As needed & Excel & $\begin{array}{l}\text { Inhaler usage records, including time, date, } \\
\text { medication name (Ventolin), dose strength, } \\
\text { event }\end{array}$ \\
\hline $\begin{array}{l}\text { E-spirometer } \\
* *\end{array}$ & Daily & Excel & $\begin{array}{l}\text { Spirometry test measures (with units), } \\
\text { including date, time, FVC (L), FEV } 1(\mathrm{~L}) \text {, } \\
\mathrm{FEV}_{6}(\mathrm{~L}), \mathrm{FEV} / \mathrm{FVC}(\%), \mathrm{FEF} 25-75(\mathrm{~L} / \mathrm{s}) \text {, } \\
\text { and PEF (L/m) }\end{array}$ \\
\hline Mi-Band & 15 minutes & CSV & $\begin{array}{l}\text { Start date and time, end date and time, } \\
\text { calories }(\mathrm{kcal}) \text {, distance }(\mathrm{m}), \\
\text { average } / \mathrm{min} / \mathrm{max} \text { speed }(\mathrm{m} / \mathrm{s}) \text {, walking } \\
\text { duration }(\mathrm{s}) \text {, running duration (s), step count, } \\
\text { move minutes count }\end{array}$ \\
\hline \multicolumn{4}{|c|}{$\begin{array}{l}\text { Notes: } \\
\text { * The e-inhaler records the following events, including "inhaler installed", "inhaler } \\
\text { removed", and "medication". } \\
\text { ** Each participant is required to perform three or more repeated tests during a short } \\
\text { period in a day. Each spirometry test is marked with a quality assessment label, including } \\
\text { "Good blow", "Blow out faster", "Blow out longer", "Don't hesitate", "Abrupt end", and } \\
\text { "Don't start too early". }\end{array}$} \\
\hline
\end{tabular}

(d) Health perception

\begin{tabular}{|l|l|l|l|}
\hline Instrument & $\begin{array}{l}\text { Sampling } \\
\text { frequency }\end{array}$ & Data format & Data types \\
\hline $\begin{array}{l}\text { Paper-based } \\
\text { survey }\end{array}$ & Weekly & CSV & Self-reported Asthma Control Test (ACT) \\
\hline $\begin{array}{l}\text { Paper-based } \\
\text { survey }\end{array}$ & Weekly & CSV & $\begin{array}{l}\text { Self-reported Asthma Quality of Life } \\
\text { Questionnaire (AQLQ) }\end{array}$ \\
\hline
\end{tabular}

\subsection{Data Pre-processing}

The PM exposure and meteorology data were sampled every minute by the portable sensor. In the raw tabular data, $19 \%$ of the rows consisted of at least one missing $\mathrm{PM}$ value $\left(\mathrm{PM}_{1.0}, \mathrm{PM}_{2.5}\right.$, or $\mathrm{PM}_{10}$ ). We used an iterative imputer (Bayesian Ridge Regression) [6] to fill in the missing PM values based on the relationship between one feature and the others, utilizing the available 
medRxiv preprint doi: https://doi.org/10.1101/2021.06.22.21259358; this version posted June 25, 2021. The copyright holder for this preprint (which was not certified by peer review) is the author/funder, who has granted medRxiv a license to display the preprint in All rights reserved. No reuse allowed without permission.

data points, including $\mathrm{PM}_{1.0}, \mathrm{PM}_{2.5}, \mathrm{PM}_{10}$, temperature, and relative humidity. After missing data imputation, PM exposure and meteorology values were aggregated into hourly median values to reduce the impact of extreme values at the minute level. Hourly values were further aggregated into daily mean values to represent the daily average air pollution exposure.

Moreover, spirometry tests were performed by the study participants daily (at least three repeated tests during a short period). We only selected spirometry tests with "good blow" labels to reduce the potential measurement errors. Spirometry values were aggregated into daily maximum values.

Further, we calculated the mean and standard deviation of the daily PM and spirometry values. Any values out of the normal range (mean $\pm 3 \times$ standard deviation) were considered outliers and removed.

\subsection{Statistical Analysis}

After data pre-processing, we performed a preliminary analysis to examine the relationship between personal air pollutant exposures and personal health conditions and health perceptions. The key variables are listed as follows.

Health conditions refer to objective assessments of one's own health. For health conditions, the primary outcomes are the two lung function indicators that have been widely used in previous medical studies: $\mathrm{FEV}_{1}$, which measures how much air one can exhale during a forced breath during the first second, and FVC, which measures the total amount of air exhaled during the FEV test [7]. In addition, the secondary outcome is the number of asthmatic medications received by the subject as recorded by the e-inhaler.

Health perceptions refer to subjective assessments of one's own health and well-being. For health perception, the primary outcomes are the ACT and AQLQ scores measured weekly. The ACT score is calculated using a standardized self-reported questionnaire that measures how well the symptoms of asthma are controlled. The AQLQ score is calculated using a standardized self-reported questionnaire that evaluates the quality of life of asthmatic patients.

For personal air pollutant exposures, $\mathrm{PM}_{2.5}$ and $\mathrm{PM}_{10}$ were selected due to their welldocumented adverse health impacts in HK [8]. Moreover, $\mathrm{PM}_{1.0}$ was included in our analysis, given that the adverse health impacts of $\mathrm{PM}_{1.0}$ may be stronger than $\mathrm{PM}_{2.5}$ [9]. Further, demographic information, including age (number of years), gender (male or female), and body mass index (BMI), and meteorology information, including temperature (degree Celsius) and relative humidity $(\%)$, were included as covariates [10-12]. BMI $\left(\mathrm{kg} / \mathrm{m}^{2}\right)$ is calculated as the body weight divided by the square of the body height. 
medRxiv preprint doi: https://doi.org/10.1101/2021.06.22.21259358; this version posted June 25, 2021. The copyright holder for this preprint (which was not certified by peer review) is the author/funder, who has granted medRxiv a license to display the preprint in All rights reserved. No reuse allowed without permission.

For each health condition and perception outcome, a univariate linear regression analysis was performed to examine the relationship between the personal air pollutant exposure variable and the outcome variable. A multivariate linear regression analysis was also performed to examine the statistical relationship after controlling for covariates. All variables were measured at the daily level (except for the three demographic variables). Single-pollutant models were used due to the collinearity between $\mathrm{PM}_{1.0}, \mathrm{PM}_{2.5}$, and $\mathrm{PM}_{10}$. Two-sided $p$-value $<0.05$ was considered statistically significant.

\section{Preliminary Results and Discussions}

\subsection{Preliminary Results}

After data pre-processing, 44 daily observations were obtained. Table 2 a shows the characteristics of the study subjects. Table $2 \mathrm{~b}$ shows the descriptive statistics of the exposure and outcome variables after removing outliers, including the mean, standard deviation (SD), median, and interquartile range (IQR) values. The level of average PM exposure during the study period is relatively low, given that the study subjects often stayed at home (especially during the Covid-19 period) and indoor PM exposure is lower than outdoor levels in homes without strong PM sources.

Table 2. Descriptive statistics

(a) Characteristics of the asthma subjects

\begin{tabular}{|l|l|}
\hline Variable & Characteristic \\
\hline Age: mean (range) & $13.1(12-15)$ \\
\hline Gender: percentage & \\
\hline Male & $50 \%$ \\
\hline Female & $50 \%$ \\
\hline BMI: mean (range) & $19.5(16.3-24.4)$ \\
\hline
\end{tabular}

(b) Descriptive statistics of daily exposure and outcome variables

\begin{tabular}{|l|l|l|l|}
\hline Variable (number of observations) & Mean \pm SD & Median & IQR \\
\hline 24-h average $\mathrm{PM}_{1.0}(n=43)$ & $3.82 \pm 2.18$ & 3.38 & 1.98 \\
\hline 24-h average $\mathrm{PM}_{2.5}(n=43)$ & $4.48 \pm 2.39$ & 4.07 & 2.21 \\
\hline 24-h average $\mathrm{PM}_{10}(n=44)$ & $5.37 \pm 2.98$ & 4.64 & 3.38 \\
\hline $\mathrm{FEV}_{1}(n=44)$ & $2.61 \pm 0.61$ & 2.37 & 0.96 \\
\hline
\end{tabular}


medRxiv preprint doi: $h t t p s: / / d o i . o r g / 10.1101 / 2021.06 .22 .21259358$; this version posted June 25, 2021. The copyright holder for this preprint (which was not certified by peer review) is the author/funder, who has granted medRxiv a license to display the preprint in All rights reserved. No reuse allowed without permission.

\begin{tabular}{|l|l|l|l|}
\hline FVC $(n=44)$ & $3.23 \pm 0.81$ & 3.05 & 1.26 \\
\hline
\end{tabular}

For the univariate relationship between personal air pollutant exposures and health conditions measured by $\mathrm{FEV}_{1}$ and $\mathrm{FVC}$, we determined that all correlations are significant and negative, including $\mathrm{PM}_{1.0}$ exposure vs. $\mathrm{FEV}_{1}\left(\mathrm{R}^{2}=12 \%\right.$; $p=0.023$; Figure 1a), $\mathrm{PM}_{1.0}$ exposure vs. FVC ( $\mathrm{R}^{2}=15 \% ; p=0.010$; Figure $\left.1 \mathrm{~b}\right), \mathrm{PM}_{2.5}$ exposure vs. $\mathrm{FEV}_{1}\left(\mathrm{R}^{2}=13 \% ; p=0.019\right.$; Figure 1c), $\mathrm{PM}_{2.5}$ exposure vs. FVC ( $\mathrm{R}^{2}=16 \%$; $p=0.008$; Figure $\left.1 \mathrm{~d}\right), \mathrm{PM}_{10}$ exposure vs. $\mathrm{FEV}_{1}\left(\mathrm{R}^{2}=14 \%\right.$; $p=0.012$; Figure 1e), and $\mathrm{PM}_{10}$ exposure vs. FVC $\left(\mathrm{R}^{2}=18 \% ; p=0.005\right.$; Figure 1f $)$.
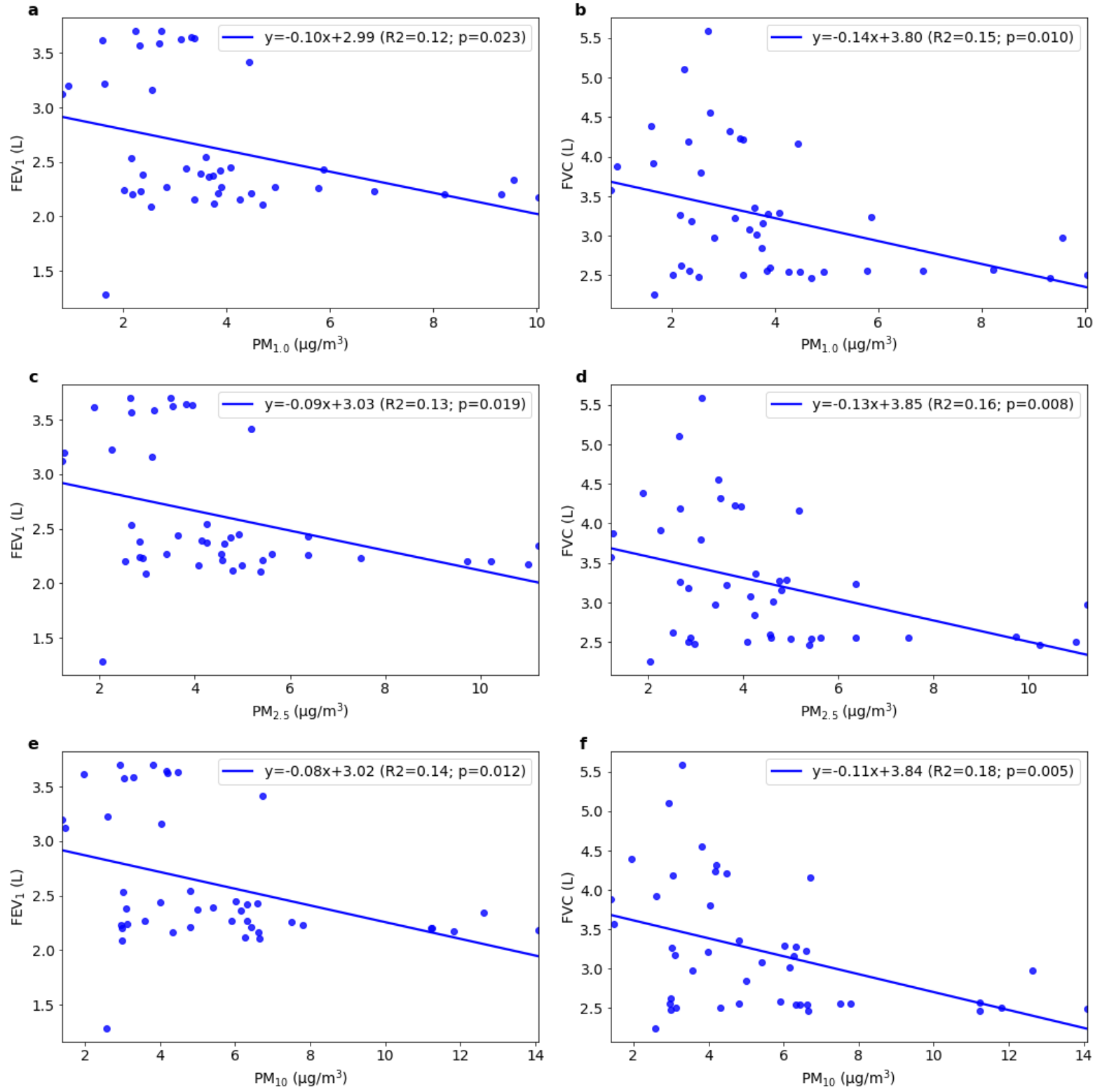

Figure 1. The univariate relationship between (a) daily personal $\mathrm{PM}_{1.0}$ exposure vs. $\mathrm{FEV}_{1}$, (b) daily personal $\mathrm{PM}_{1.0}$ exposure vs. FVC, (c) daily personal $\mathrm{PM}_{2.5}$ exposure vs. $\mathrm{FEV}_{1}$, (d) daily 
medRxiv preprint doi: https://doi.org/10.1101/2021.06.22.21259358; this version posted June 25, 2021. The copyright holder for this preprint (which was not certified by peer review) is the author/funder, who has granted medRxiv a license to display the preprint in All rights reserved. No reuse allowed without permission.

personal $\mathrm{PM}_{2.5}$ exposure vs. FVC, (e) daily personal $\mathrm{PM}_{10}$ exposure vs. $\mathrm{FEV}_{1}$, and (f) daily personal $\mathrm{PM}_{10}$ exposure vs. FVC

Moreover, after accounting for covariates, including age, gender, BMI, temperature, and relative humidity, we found a significant relationship between $\mathrm{PM}_{1.0}$ exposure vs. FVC (Coefficient=-0.1224; $p=0.032$; Table 3a), $\mathrm{PM}_{2.5}$ exposure vs. FVC (Coefficient=-0.1177; $p=0.021$; Table 3b), $\mathrm{PM}_{10}$ exposure vs. $\mathrm{FEV}_{1}$ (Coefficient=-0.0703; $p=0.019$; Table 3c), and $\mathrm{PM}_{10}$ exposure vs. FVC (Coefficient=-0.1204; $p=0.006$; Table 3d). However, the following two statistical correlations are negative and insignificant after controlling for covariates: $\mathrm{PM}_{1.0}$ exposure vs. FEV 1 (Coefficient=-0.0679; $p=0.084)$ and $\mathrm{PM}_{2.5}$ exposure vs. $\mathrm{FEV}_{1}$ (Coefficient=$0.0622 ; p=0.059)$.

Table 3. The significant relationship between PM exposure and spirometry after adjusting for covariates

(a) PM1.0 vs. FVC

\begin{tabular}{|c|c|c|c|}
\hline \multicolumn{4}{|c|}{$\begin{array}{l}\text { Dependent Variable: FVC } \\
\text { Number of Observations: } 43 \\
\text { Adjusted } \mathbf{R}^{\mathbf{2}}: 38.6 \%\end{array}$} \\
\hline Variable & Coefficient & 95\% Confidence Interval & $p$-value \\
\hline Intercept & 5.1497 & {$[-2.283,12.583]$} & 0.169 \\
\hline Age & -0.3435 & {$[-1.183,0.496]$} & 0.412 \\
\hline Gender [=male] & -1.1810 & {$[-2.798,0.436]$} & 0.147 \\
\hline BMI & 0.4250 & {$[0.036,0.814]$} & $0.033 *$ \\
\hline Temperature & -0.1523 & {$[-0.368,0.063]$} & 0.160 \\
\hline Relative humidity & -0.0035 & {$[-0.019,0.012]$} & 0.661 \\
\hline $\mathrm{PM}_{1.0}$ exposure & -0.1224 & {$[-0.234,-0.011]$} & $0.032 *$ \\
\hline
\end{tabular}

(b) $\mathrm{PM}_{2.5}$ vs. FVC

Dependent Variable: FVC

Number of Observations: 43

Adjusted R': $39.8 \%$

\begin{tabular}{|l|l|l|l|}
\hline Variable & Coefficient & $95 \%$ Confidence Interval & $p$-value
\end{tabular}


medRxiv preprint doi: https://doi.org/10.1101/2021.06.22.21259358; this version posted June 25, 2021. The copyright holder for this preprint (which was not certified by peer review) is the author/funder, who has granted medRxiv a license to display the preprint in All rights reserved. No reuse allowed without permission.

\begin{tabular}{|l|l|l|l|}
\hline Intercept & 5.2988 & {$[-2.026,12.624]$} & 0.151 \\
\hline Age & -0.3559 & {$[-1.187,0.476]$} & 0.391 \\
\hline Gender [=male] & -1.2325 & {$[-2.838,0.373]$} & 0.128 \\
\hline BMI & 0.4340 & {$[0.049,0.819]$} & $0.028 *$ \\
\hline Temperature & -0.1554 & {$[-0.366,0.056]$} & 0.144 \\
\hline Relative humidity & -0.0033 & {$[-0.019,0.012]$} & 0.674 \\
\hline PM $_{2.5}$ exposure & -0.1177 & {$[-0.217,-0.019]$} & $0.021 *$ \\
\hline$* p$-value $<0.05$ & \multicolumn{3}{|l|}{} \\
\hline
\end{tabular}

(c) $\mathrm{PM}_{10}$ vs. FEV 1

\begin{tabular}{|c|c|c|c|}
\hline \multicolumn{4}{|c|}{$\begin{array}{l}\text { Dependent Variable: } \mathrm{FEV}_{1} \\
\text { Number of Observations: } 44 \\
\text { Adjusted } \mathbf{R}^{2}: 51.1 \%\end{array}$} \\
\hline Variable & Coefficient & 95\% Confidence Interval & $p$-value \\
\hline Intercept & 1.9995 & {$[-2.986,6.985]$} & 0.422 \\
\hline Age & -0.0341 & {$[-0.596,0.528]$} & 0.903 \\
\hline Gender [=male $]$ & -0.2939 & {$[-1.396,0.809]$} & 0.592 \\
\hline BMI & 0.2400 & {$[-0.023,0.503]$} & 0.072 \\
\hline Temperature & -0.1125 & {$[-0.253,0.028]$} & 0.112 \\
\hline Relative humidity & 0.0008 & {$[-0.010,0.011]$} & 0.885 \\
\hline $\mathrm{PM}_{10}$ exposure & \begin{tabular}{|l|}
-0.0703 \\
\end{tabular} & {$[-0.128,-0.012]$} & $0.019 *$ \\
\hline
\end{tabular}

(d) $\mathrm{PM}_{10}$ vs. FVC

\begin{tabular}{|c|c|c|c|}
\hline \multicolumn{4}{|c|}{$\begin{array}{l}\text { Dependent Variable: FVC } \\
\text { Number of Observations: } 44 \\
\text { Adjusted } \mathbf{R}^{2}: 43.9 \%\end{array}$} \\
\hline Variable & Coefficient & 95\% Confidence Interval & $p$-value \\
\hline Intercept & 6.1363 & {$[-0.985,13.257]$} & 0.089 \\
\hline Age & -0.4229 & {$[-1.226,0.380]$} & 0.293 \\
\hline Gender [=male $]$ & -1.4506 & {$[-3.026,0.124]$} & 0.070 \\
\hline BMI & 0.4782 & {$[0.103,0.853]$} & $0.014 *$ \\
\hline Temperature & -0.1800 & {$[-0.380,0.020]$} & 0.077 \\
\hline
\end{tabular}


medRxiv preprint doi: https://doi.org/10.1101/2021.06.22.21259358; this version posted June 25, 2021. The copyright holder for this preprint (which was not certified by peer review) is the author/funder, who has granted medRxiv a license to display the preprint in All rights reserved. No reuse allowed without permission.

\begin{tabular}{|l|l|l|l|}
\hline Relative humidity & -0.0021 & {$[-0.017,0.013]$} & 0.779 \\
\hline $\mathrm{PM}_{10}$ exposure & -0.1204 & {$[-0.204,-0.037]$} & $0.006 *$ \\
\hline$* p$-value $<0.05$ & & \\
\hline
\end{tabular}

The statistical relationship between personal air pollutant exposure and asthma medication is yet to be conclusive due to the lack of data. Observations on the total number of e-inhaler doses are very limited. Similarly, the number of health perception data points is too limited. With regard to the asthma control survey, very little about the symptoms of the asthmatics has been reported over the study period. With regard to the asthma-related qualityof-life survey, the quality-of-life indicators show very little variation. In view of this, we have put forward new practical suggestions on how to motivate our young asthmatic subjects to respond more actively to the health condition and perception surveys.

\subsection{Discussions}

Our preliminary results show that a higher level of $\mathrm{PM}_{1.0}, \mathrm{PM}_{2.5}$ and $\mathrm{PM}_{10}$ would deteriorate the health conditions of young asthmatics in $\mathrm{HK}$, as shown by a lower $\mathrm{FEV}_{1}$ and a lower FVC value. This is the first study to investigate the relationship between $\mathrm{PM}_{1.0}$ and $\mathrm{FEV}_{1}$ and FVC of young asthmatics in Hong Kong, based on personal exposures obtained from portable sensors.

Results of our pilot study also provide insights on the proper effect size of our followup study. Following the previous studies on personal air pollutant exposure and lung function [10-12], we have adjusted the regression coefficients based on one IQR change in $\mathrm{PM}_{2.5}$ exposure level. For one IQR change in personal $\mathrm{PM}_{2.5}$ exposure, the change in $\mathrm{FEV}_{1}$ and $\mathrm{FVC}$ was -0.137 and -0.260 , respectively. We found that the effect size in our study, as represented by the adjusted regression coefficient, is larger than the previous studies (Table 4).

Table 4. A comparison of the effects of personal air pollutant exposures on lung functions

\begin{tabular}{|l|l|l|l|l|}
\hline Subject Selection and Sample Size & Outcome & $\begin{array}{l}\text { Personal } \\
\text { Exposure }\end{array}$ & Coefficient * & Reference \\
\hline 36 healthy college students & $\mathrm{FEV}_{1}$ & $\mathrm{PM}_{2.5}$ & -0.011 & {$[10]$} \\
\hline 36 healthy college students & $\mathrm{FVC}$ & $\mathrm{PM}_{2.5}$ & -0.007 & {$[10]$} \\
\hline $\begin{array}{l}53 \text { asthmatic schoolchildren (aged } \\
9 \text { to } 18 \text { years old) }\end{array}$ & $\mathrm{FEV}_{1}$ & $\mathrm{PM}_{2.5}$ & -0.059 & {$[11]$} \\
\hline
\end{tabular}




\begin{tabular}{|l|l|l|l|l|}
\hline $\begin{array}{l}43 \text { asthmatic children (aged 5 to 13 } \\
\text { years old) }\end{array}$ & $\mathrm{FEV}_{1}$ & $\mathrm{PM}_{2.5}$ & -0.024 & {$[12]$} \\
\hline $\begin{array}{l}43 \text { asthmatic children (aged 5 to 13 } \\
\text { years old) }\end{array}$ & $\mathrm{FVC}$ & $\mathrm{PM}_{2.5}$ & -0.017 & {$[12]$} \\
\hline $\begin{array}{l}9 \text { asthmatic schoolchildren (aged } \\
12 \text { to } 15 \text { years old) }\end{array}$ & $\mathrm{FEV}_{1}$ & $\mathrm{PM}_{2.5}$ & $\mathbf{- 0 . 1 3 7}$ & Pilot study \\
\hline $\begin{array}{l}9 \text { asthmatic schoolchildren (aged } \\
12 \text { to } 15 \text { years old) }\end{array}$ & $\mathrm{FVC}$ & $\mathrm{PM}_{2.5}$ & $\mathbf{- 0 . 2 6 0}$ & Pilot study \\
\hline $\begin{array}{l}\text { Notes: } \\
*\end{array}$ & & & \\
To compare the effects of personal air pollution on health outcomes across different \\
change in air pollution level after adjusting for covariates [10-12].
\end{tabular}

Further, using the pilot study data, we have performed a power analysis to estimate the sample size for our follow-up main study. The primary null hypothesis is that personal PM exposure would not change the $\mathrm{FEV}_{1}$ and $\mathrm{FVC}$ of young asthmatics in $\mathrm{HK}$. To better measure the local effect size of personal air pollution exposure in a multivariate regression context, we calculated Cohen's $f^{2}$ value [13] based on (1) the adjusted $\mathrm{R}^{2}$ value of each regression model shown in Table 3 and (2) the adjusted $\mathrm{R}^{2}$ value of the corresponding regression model without the PM exposure variable. We found that the Cohen's $f^{2}$ value ranges from 0.107 to 0.200 . Then, using the effect size of 0.107 , we performed a two-sided $\mathrm{F}$ test under a multivariate linear regression setting (three predictors to be tested and ten predictors in total) [14] to calculate the sample size that gives $80 \%$ power at a $5 \%$ significance level. We found that the lowest number of asthmatic subjects is 107 . After accounting for a potential non-compliance and dropout rate of $10 \%$ to $15 \%$ (given that children in HK normally show much higher compliance), we determined that 125 asthmatic subjects are sufficient for our main study. Moreover, to obtain more rigorous statistical findings by comparing the difference between the asthmatic subjects and healthy subjects, 125 healthy subjects will also be enrolled in our main study in a 1:1 ratio.

Our follow-up main study will collect more longitudinal health condition and perception and air pollutant exposure data from 125 asthmatic subjects and 125 healthy subjects. This longitudinal dataset will help us better investigate the statistical relationship between personal air pollutant exposure and health condition and perception, by utilizing more advanced statistical modelling to account for (1) the repeated measures of health outcomes and 
medRxiv preprint doi: https://doi.org/10.1101/2021.06.22.21259358; this version posted June 25,2021 . The copyright holder for this preprint (which was not certified by peer review) is the author/funder, who has granted medRxiv a license to display the preprint in All rights reserved. No reuse allowed without permission.

(2) the lag effects of personal air pollutant exposure. We expect to obtain more rigorous statistical findings in our upcoming main clinical study.

\section{Major Challenges of the Pilot Study}

As hospitals and clinics have focused on combatting COVID-19, the recruitment of subjects has been adversely affected. The Hospital Authority has required all non-urgent cases to stay away from hospitals to minimize risks. Additional challenges in data collection and statistical analysis are listed below (See solutions to overcome such challenges in Section 5).

\subsection{Missing Data}

Notable missing values have been observed in the data collected from different types of sensors. During the pilot study, the missing data can be due to human errors (e.g., the subject may forget to perform the required actions) or data transmission errors (e.g., the sensor/phone may fail to connect to the internet).

\subsection{Automated Data Collection}

The data collection process is yet to be fully automated and monitored. In the pilot study, the data collected from the e-inhaler, e-spirometer, and Mi-Band were downloaded and processed manually before further analysis. Moreover, the questionnaires are yet to be automated and conducted online.

\subsection{Statistical Modeling for Longitudinal Data}

Due to the small number of data points, advanced statistical models for longitudinal data, such as linear mixed-effect models, are yet to be utilized.

\section{Follow-up Actions and Directions}

The major challenges of the pilot study are interlinked. By improving our data collection procedure and engaging with more participants, we expect to establish a high-quality longitudinal dataset for advanced statistical analysis. More specifically, to overcome these challenges, our follow-up work can be divided into two main directions: (1) improving data collection and analysis and (2) increasing and mobilizing subject engagement.

\subsection{Data Collection and Analysis}

\subsubsection{Building an Integrated Data Management Platform}


medRxiv preprint doi: https://doi.org/10.1101/2021.06.22.21259358; this version posted June 25, 2021. The copyright holder for this preprint (which was not certified by peer review) is the author/funder, who has granted medRxiv a license to display the preprint in

All rights reserved. No reuse allowed without permission.

We are building an integrated data management platform to automatically collect, process, monitor, and manage the data across all sources, utilizing a cloud computing server equipped with strong measures for user privacy and data security. So far, the portable sensor data collection procedure has been successfully integrated into the data management platform. Moreover, an alert system, as a part of the data management platform, will be deployed to identify and fix data synchronization and transmission issues, and issue missing data alerts to (1) inform the study team to take action and (2) remind the subjects to follow the data collection procedure closely.

\subsubsection{Calibrating Air Pollution Data}

Calibrating air pollution data can reduce the measurement errors and allow the subjects to better understand the risks of his/her exposure. In the portable sensor, PM pollutants are measured by a laser particle counter. The PM sensor can be calibrated based on the raw data (bin counts for a range of particle size bins) while accounting for meteorology factors [15]. Our sensor calibration can be performed seasonally to capture the seasonal variation of air pollution in $\mathrm{HK}$ (for more details, please refer to our sensor calibration report).

\subsubsection{Integrating E-surveys into the UMeAir App}

We are integrating the e-surveys into the UMeAir App and the data management platform, based on a separate online e-survey system developed by us previously. The UMeAir App will motivate the subjects to fill in the surveys on time with gentle musical alerts. We will also look for more incentive and empowerment measures to our young participants, along the line of good citizenship recognition/differentiation; such as running smart competitions for our participants with chances of visiting our new HKU innovation facilities online, opportunities of visiting online new high-tech start-ups in HK or Israel, inviting our participants to our UMeAir Club as VIPs, and awarding certificates of green, healthy and smart citizenship to our VIPs, in order to improve the quality of questionnaire data collection.

\subsubsection{Improving the Statistical Analysis}

After collecting more longitudinal data with higher data integrity and fewer missing values, we aim to improve the current statistical methodology. We will adopt advanced statistical models (such as the linear mixed-effect models) to account for the repeated measurements and the lagged effects of air pollutant exposure, while controlling for important confounders and autocorrelation in longitudinal data. We will also address non-linearity and multicollinearity if 
medRxiv preprint doi: https://doi.org/10.1101/2021.06.22.21259358; this version posted June 25, 2021. The copyright holder for this preprint (which was not certified by peer review) is the author/funder, who has granted medRxiv a license to display the preprint in All rights reserved. No reuse allowed without permission.

any are found in our follow-up study. We expect to obtain more rigorous statistical findings in our follow-up study.

\subsection{Subject Engagement and Recruitment}

\subsubsection{Troubleshooting Equipment Usage in Close Collaboration with QMH}

During the pilot study, considerable data gaps for most of the sensors and measurements were identified. While data collection automation will help, increasing the accessibility of the sensors and reducing technical barriers of the subjects can improve the engagement of the subjects and thus the integrity of the data. We are working closely with QMH staff to produce a series of instructional videos for the usage of different sensors for the study and provide timely technical assistance to both the staff and subjects.

\subsubsection{Recruitment of Healthy Subjects}

In order to provide an effective control group, we are currently proceeding with the recruitment of healthy subjects for the pilot study. However, due to the suspension of schools as a result of the ongoing COVID-19 pandemic, there are difficulties in the recruitment of students. We are working closely with schools and starting to install air pollution sensors in schools. Meanwhile we shall recruit the healthy subjects from schools.

\section{Conclusion}

This report provides a summary of the current progress made in the TBR Air Pollution Clinical and Quality of Life Study. We determine that all correlations are significant and negative, including $\mathrm{PM}_{1.0}$ exposure vs. $\mathrm{FEV}_{1}\left(\mathrm{R}^{2}=12 \%\right.$; $p=0.023$; Figure $\left.1 \mathrm{a}\right), \mathrm{PM}_{1.0}$ exposure vs. FVC $\left(\mathrm{R}^{2}=15 \% ; p=0.010\right.$; Figure 1b), $\mathrm{PM}_{2.5}$ exposure vs. $\mathrm{FEV}_{1}\left(\mathrm{R}^{2}=13 \% ; p=0.019 ;\right.$ Figure $\left.1 \mathrm{c}\right), \mathrm{PM}_{2.5}$ exposure vs. FVC $\left(\mathrm{R}^{2}=16 \% ; p=0.008\right.$; Figure $\left.1 \mathrm{~d}\right), \mathrm{PM}_{10}$ exposure vs. $\mathrm{FEV}_{1}\left(\mathrm{R}^{2}=14 \% ; p=0.012\right.$; Figure 1e), and $\mathrm{PM}_{10}$ exposure vs. FVC $\left(\mathrm{R}^{2}=18 \%\right.$; $p=0.005$; Figure 1f). Moreover, after accounting for covariates, including age, gender, BMI, temperature, and relative humidity, we found a significant relationship between $\mathrm{PM}_{1.0}$ exposure vs. FVC (Coefficient=-0.1224; $p=0.032$; Table 3a), $\mathrm{PM}_{2.5}$ exposure vs. FVC (Coefficient=-0.1177; $p=0.021$; Table 3b), $\mathrm{PM}_{10}$ exposure vs. FEV 1 (Coefficient=-0.0703; $p=0.019$; Table $3 \mathrm{c}$ ), and $\mathrm{PM}_{10}$ exposure vs. FVC (Coefficient=-0.1204; $p=0.006$; Table 3d). Further, using the pilot study data, we have performed a power analysis to estimate the sample size for our follow-up main study. Based on the primary null hypothesis is that personal PM exposure would not change the $\mathrm{FEV}_{1}$ and FVC of young asthmatics in HK, the lowest sample size that gives $80 \%$ power at a $5 \%$ 
significance level is 107 . Hence, the sample size (or the total number of participated asthma subjects) expected for the follow-up longitudinal clinical study should be 125 (after adjusting for the non-compliance and withdrawal of subjects). Our pilot study has demonstrated the feasibility of research into the effects of personal air pollutant exposure on health condition and health perception. Our follow-up study will address the challenges identified in the pilot study, based on the proposed follow-up actions for subject engagement, data collection, and data analysis.

\section{Acknowledgement}

We acknowledge the assistance of Miss Jennifer Lam, Research Nurse, Department of Pediatrics, Queen Mary Hospital, Hong Kong, in training recruited asthma subjects in using the medical and air pollution sensor devices, and in collecting clinical trial data. We also thank Mr. Andong Wang for his research assistance in this clinical trial project.

\section{References}

[1] James Gauderman, W., McConnell, R. O. B., Gilliland, F., London, S., Thomas, D., Avol, E., ... \& Peters, J. (2000). Association between air pollution and lung function growth in southern California children. American journal of respiratory and critical care medicine, 162(4), 1383-1390.

[2] Eckel, S. P., Berhane, K., Salam, M. T., Rappaport, E. B., Linn, W. S., Bastain, T. M., ... \& Gilliland, F. D. (2011). Residential traffic-related pollution exposures and exhaled nitric oxide in the children's health study. Environmental Health Perspectives, 119(10), 1472-1477. [3] Urman, R., Gauderman, J., Fruin, S., Lurmann, F., Liu, F., Hosseini, R., ... \& McConnell, R. (2014). Determinants of the spatial distributions of elemental carbon and particulate matter in eight southern Californian communities. Atmospheric Environment, 86, 84-92.

[4] Gauderman, W. J., Urman, R., Avol, E., Berhane, K., McConnell, R., Rappaport, E., ... \& Gilliland, F. (2015). Association of improved air quality with lung development in children. New England Journal of Medicine, 372, 905-913.

[5] Anderson, J. O., Thundiyil, J. G., \& Stolbach, A. (2012). Clearing the air: a review of the effects of particulate matter air pollution on human health. Journal of Medical Toxicology, 8(2), 166-175.

[6] Buuren, S. V., \& Groothuis-Oudshoorn, K. (2010). mice: Multivariate imputation by chained equations in R. Journal of Statistical Software, 1-68. 
medRxiv preprint doi: https://doi.org/10.1101/2021.06.22.21259358; this version posted June 25, 2021. The copyright holder for this preprint (which was not certified by peer review) is the author/funder, who has granted medRxiv a license to display the preprint in All rights reserved. No reuse allowed without permission.

[7] Swanney, M. P., Ruppel, G., Enright, P. L., Pedersen, O. F., Crapo, R. O., Miller, M. R., ... \& Quanjer, P. H. (2008). Using the lower limit of normal for the $\mathrm{FEV}_{1} / \mathrm{FVC}$ ratio reduces the misclassification of airway obstruction. Thorax, 63(12), 1046-1051.

[8] HKEPD. (n.d.). Health Effects of Air Pollutants - Respirable and Fine Suspended Particles $\left(\mathrm{PM}_{10}\right.$ and $\left.\mathrm{PM}_{2.5}\right)$. Retrieved from https://www.aqhi.gov.hk/en/health-advice/health-effects-ofair-pollutants9b5f.html on February 4, 2021.

[9] Yang, M., Guo, Y. M., Bloom, M. S., Dharmagee, S. C., Morawska, L., Heinrich, J., ... \& Dong, G. H. (2020). Is $\mathrm{PM}_{1}$ similar to $\mathrm{PM}_{2.5}$ ? A new insight into the association of PM1 and PM2.5 with children's lung function. Environment International, 145, 106092.

[10] Wang, C., Cai, J., Chen, R., Shi, J., Yang, C., Li, H., ... \& Kan, H. (2017). Personal exposure to fine particulate matter, lung function and serum club cell secretory protein (Clara). Environmental Pollution, 225, 450-455.

[11] Delfino, R. J., Staimer, N., Tjoa, T., Gillen, D., Kleinman, M. T., Sioutas, C., \& Cooper, D. (2008). Personal and ambient air pollution exposures and lung function decrements in children with asthma. Environmental Health Perspectives, 116(4), 550-558.

[12] He, L., Norris, C., Cui, X., Li, Z., Barkjohn, K. K., Brehmer, C., ... \& Zhang, J. J. (2021). Personal Exposure to $\mathrm{PM}_{2.5}$ Oxidative Potential in Association with Pulmonary Pathophysiologic Outcomes in Children with Asthma. Environmental Science \& Technology, 55(5), 3101-3111.

[13] Selya, A. S., Rose, J. S., Dierker, L. C., Hedeker, D., \& Mermelstein, R. J. (2012). A practical guide to calculating Cohen's f2, a measure of local effect size, from PROC MIXED. Frontiers in Psychology, 3, 111.

[14] Faul, F., Erdfelder, E., Buchner, A., \& Lang, A. G. (2009). Statistical power analyses using $\mathrm{G}^{*}$ Power 3.1: Tests for correlation and regression analyses. Behavior Research Methods, 41(4), 1149-1160.

[15] Chatzidiakou, L., Krause, A., Popoola, O. A., Antonio, A. D., Kellaway, M., Han, Y., ... \& Jones, R. L. (2019). Characterising low-cost sensors in highly portable platforms to quantify personal exposure in diverse environments. Atmospheric measurement techniques, 12(8), 4643-4657. 